\title{
Inventarisasi Kumbang Kura-Kura (Cassidinae) pada Kawasan Ekosistem Persawahan Pasca Panen di Desa Serdang Menang, Kecamatan Sirah Pulau Padang
}

\author{
Ari Sugiarto \\ Email: sugiartoari13@gmail.com
}

\begin{abstract}
Abstrak
Keanekaragaman spesies tanaman pada kawasan ekosistem persawahan pasca panen cendrung lebih tinggi dibanding saat sebelum panen. Kumbang kura-kura dapat menjadi ancaman terhadap spesies tanaman yang ada pada kawasan ekosistem persawahan. Desa Serdang Menang memiliki kawasan ekosistem persawahan yang cukup luas. Inventarisasi kumbang kura-kura pada kawasan ekosistem persawahan di Desa Serdang Menang akan sangat membantu dalam memperkirakan potensi acaman dari kumbang kura-kura ini terhadap tanaman yang ada pada kawasan ekosistem persawahan di Desa Serdang Menang. Penentuan lokasi sampling ini dilakukan secara acak pada kawasan ekosistem persawahan pasca panen di Desa Serdang Menang. Metode pengambilan sampel menggunakan metode hand picking dan insecting net berukuran kecil. Spesies kumbang kura-kura yang ditemukan berjumlah 5 spesies (Aspidomorpha miliaris, Cassida subreticulata, Cassida circumdata, Cassida sp., dan Doloyala sp.) dari total 3 genus. Cassida circumdata dan Aspidomorpha miliaris merupakan spesies kumbang kura-kura yang paling mudah untuk ditemukan pada kawasan ekosistem persawahan ini yang mengindikasikan bahwa populasinya lebih banyak daripada spesies kumbang kura-kura lain yang ditemukan. Cassida circumdata dan Aspidomorpha miliaris dapat menjadi ancaman utama pada kawasan persawahan dibanding spesies kumbang kurakura lain yang ditemukan karena populasinya yang diperkirakan lebih banyak.
\end{abstract}

Kata Kunci: Kumbang kura-kura, Kawasan ekosistem persawahan pasca panen, Potensi ancaman

\section{Pendahuluan}

Kumbang kura-kura (Tortoise beetles) merupakan serangga yang termasuk dalam subfamili Cassidinae. Kubang kura-kura memiliki peran dalam mengontrol populasi tanaman terntentu. Berdasarkan penelitian Asadi et al. (2013), kumbang kura-kura dari spesies Cassida rubiginosa dapat mereduksi biomassa dari tanaman Cirsium arvense. Namun disisi lain kumbang kurakura ini dapat menjadi ancaman pada tanaman dengan memakan daun tanaman. Menurut Millar et al. (2003), kumbang kura-kura meninggalkan bekas melingkar atau tidak beraturan pada permukaan daun hingga menghilangkan sebagian besar permukaan daun sampai hanya tersisa pertulangan daun. Menurut Capinera (2015), perkembangan kubang kura-kura dari telur sampai dewasa membutuhkan waktu kira-kira 40 hari. Di ekosistem alaminya, populasi dari kumbang kura-kura ini dapat dikendalikan dengan menggunakan agen biologis Enoggera nassau, Neopolycystus insectifurax (Withers, 2014), Tetrastichus cassidus dan Eucelatoriopsis dimmocki (Capinera, 2015). Pengendalian secara kimia dapat dilakukan dengan menggunakan pelarut $\mathrm{H} 2 \mathrm{O}$ dan $\mathrm{MeOH}$, terbukti dapat menurunkan kemampuan dari perisai pada larva kumbang kura-kura (Vencl et al., 2005).

Kumbang kura-kura dapat ditemukan pada vegetasi tingkat rendah seperti pada ekosistem persawahan. Di Desa Serdang Menang, Kecamatan Sirah Pulau Padang, 
Kabupaten Ogan Komering Ilir terdapat kawasan ekosistem persawahan yang cukup luas. Pada saat pasca panen, spesies tanaman yang terdapat pada kawasan ekosistem persawahan cendrung lebih beranekaragam dibanding sabelum panen. Tingkat kenaekaragaman tanaman yang tinggi tentunya mendukung populasi dari kumbang kura-kura. Perlu dilakukannya inventarisasi kumbang kura-kura di kawasan ekosistem persawahan guna melihat potensi ancamanya terhadap spesies tanaman yang terdapat pada kawasan ekosistem persawahan di Desa Serdang Menang, Kecamatan Sirah Pulau Padang, Kabupaten Ogan Komering Ilir.

\section{Metode Penelitian}

Inventarisasi ini dilakukan dilakukan pada kawasan ekosistem persawahan pasca panen di Desa Serdang Menang, Kecamatan Sirah Pulau Padang, Kabupaten Ogan Komering Ilir pada November 2018. Penentuan lokasi sampling ditentukan secara acak pada kawasan ekosistem persawahan. Sample diambil dengan teknik hand picking dan insecting net berukuran kecil dengan pertimbangan spesies kumbang kura-kura ini relatif tenang dan jarak terbangnya tidak terlalu jauh yang memungkin mudah untuk menangkapnya. Sampel yang didapat kemudian difoto di atas kertas milimeter untuk diidentifikasi spesiesnya. Setelah difoto, kumbang kurakura yang tertangkap dilepaskan kembali untuk menjaga kelestariannya. Identifikasi spesies kumbang kura-kura yang didapat dilakukan dengan mencocokan gambar spesies kumbang kura-kura yang sudah teridentifikasi jenisnya.

\section{Hasil dan Pembahasan}

Berdasarkan inventarisasi yang telah dilakukan pada kawasan ekosistem persawahan pasca panen di Desa Serdang Menang, Kecamatan Sirah Pulau Padang, Kabupaten Ogan Komering Ilir.

Tabel 1. Spesies kumbang kura-kura yang ditemukan pada kawasan ekosistem persawahan pasca panen di Desa Serdang Menang, Kecamatan Sirah Pulau Padang, Kabupaten Ogan Komering Ilir.

\begin{tabular}{lll}
\hline Genus & Spesies & Gambar \\
\hline Aspidomorpha & Aspidomorpha miliaris & \\
\hline Cassida & Cassida subreticulata & \\
\hline
\end{tabular}




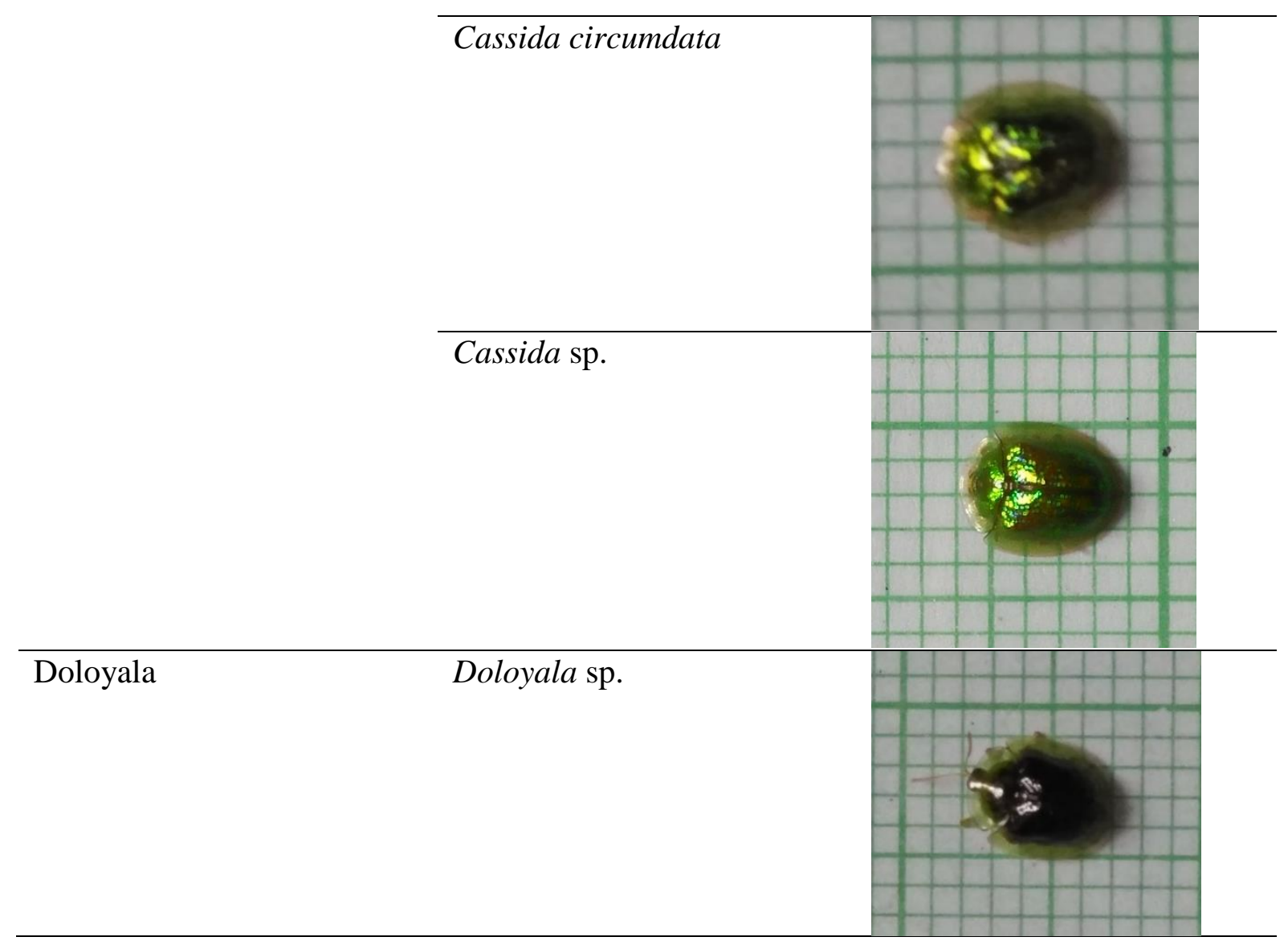

Ditemukan 5 spesies kumbang kura-kura dari total 3 genus pada kawasan ekosistem persawahan pasca panen di Desa Serdang Menang. Spesies kumbang kura-kura yang ditemukan yaitu Aspidomorpha miliaris, Cassida subreticulata, Cassida circumdata, Cassida sp., dan Doloyala sp. Spesies Cassida circumdata dan Aspidomorpha miliaris paling mudah untuk ditemukan pada kawasan ekosistem persawahan ini. Spesies kumbang kurakura yang ditemukan pada kawasan ekosistem persawahan pasca panen ini memang tidak banyak, namun jika populasinya melimpah hal ini dapat menjadi ancaman spesies tanaman yang tumbuh atau ditanam pada kawasan ekosistem persawahan ini. Menurut Millar et al. (2003), bentuk ancaman dari kumbang kura-kura yaitu memakan daun tanaman yang meninggalkan bekas melingkar atau tidak beraturan pada permukaan daun hingga menghilangkan sebagian besar permukaan daun sampai hanya tersisa pertulangan daun.
Kumbang kura-kura pada ekosistem alaminya tentu memiliki musuh yang dapat mengontrol populasi dari kumbang kurakura ini. Menurut Withers (2014) dan Capinera (2015), pada ekosistem alaminnya populasi dari kumbang kura-kura ini dapat dikendalikan dengan menggunakan agen biologis Enoggera nassau, Neopolycystus insectifurax Tetrastichus cassidus dan Eucelatoriopsis dimmocki .

Menurut Flinte et al. (2015), populasi kumbang kura-kura dari spesies Coptocycla arcuata, Omaspides trichroa, dan Platyphora axillaris pada bulan September sampai dengan Desember lebih banyak daripada populasinya pada bulan lain. Hal ini dapat menunjukkan bawah populasi kumbang kura-kura pada kawasan ekosistem persawahan di Desa Serdang Menang mamang lebih banyak ditemukan pada saat pasca panen. Musim panen di persawahan Desa Serdang Menang berada pada akhir bulan Mei sampai dengan awal bulan Agustus. Banyaknya populasi dari kumbang kura-kura pada saat pasca panen 
juga didukung dengan spesies tanaman yang terdapat pada kawasan ekosistem persawahan pasca panen lebih beranekaragam dibanding pada saat sebelum panen. Menurut Capinera (2015), perkembangan kubang kura-kura dari telur sampai dewasa membutuhkan waktu kirakira 40 hari.

Terlepas dari perkiraan dampak buruk yang ditimbulkan, tentunya kumbang kurakura ini masih memiliki peran yang penting terhadap ekosistem, seperti hasil penelitian yang dilakukan oleh Asadi et al. (2013), kumbang kura-kura dari spesies Cassida rubiginosa dapat mengontrol populasi dari tanaman Cirsium arvense dengan memakan daunny sehingga dapat mereduksi biomassa dari tanaman Cirsium arvense.

Kumbang kura-kura tidak akan menjadi ancaman pada kawasan ekosistem persawahan jika terdapat keseimbangan antara populasi dari kumbang kura-kura dan musuh alaminya. Jika hal ini terjadi, keberadaan kumbang kura-kura pada kawasan ekosistem persawahan tentunya akan memberikan dampak yang posistif. Kemampuan yang dimiliki kumbang kurakura ini dapat membantu dalam mengontrol populasi tanaman liar pada kawasan ekosistem persawahan pasca panen.

\section{Kesimpulan}

Keanekaragaman kumbang kura-kura pada kawasan ekosistem persawahan di Desa Serdang Menang tergolong sedang dengan hanya ditemukan 5 spesies dari total 3 genus. Cassida circumdata dan Aspidomorpha miliaris merupakan spesies kumbang kura-kura yang paling mudah untuk ditemukan pada kawasan ekosistem persawahan ini yang mengindikasikan bahwa populasinya lebih banyak daripada spesies kumbang kura-kura lain yang ditemukan. Cassida circumdata dan Aspidomorpha miliaris dapat menjadi ancaman utama pada kawasan persawahan dibanding spesies kumbang kura-kura lain yang ditemukan karena populasinya yang diperkirakan lebih banyak.

\section{Daftar Pustaka}

Asadi, G., Reza, G., Javad, K., Alireza, B., dan Heinz, M.Z. 2013. Host Impact and Specificity of Tortoise Beetle (Cassida rubiginosa) on Canada Thistle (Cirsium arvense) in Iran. Weed Technology. 27(2): 405-411.

Capinera, J.L. 2015. Golden Tortoise Beetle, Charidotella (=Metriona) bicolor (Fabricius) (Insecta: Coleoptera: Chrysomelidae). Gainesville: Entomology and Nematology Department; UF/IFAS Extension.

Flinte, V., Ethel, H., Barbara, M.M., Anne, C.M.L., Gabriel, K., Ricardo, F.M., Margarete, V.M. 2015. Biology and Phenology of Three Leaf Beetle Species (Chrysomelidae) in A Montane Forest in Southeast Brazil ZooKeys. 547(1): 119-132.

Millar, J.G., T.D. Paine., K.A. Campbell, R.W. Garrison, dan S.H. Dreistadt. 2003. Eucalyptus Tortoise Beetle, Integrated Pest Management for Home Gardeners and Landscape Professionals. Davis: UC Statewide IPM Program, University of California.

Vencl, F.V., Flávia, N., Bengt, J.A., Donald, M.W., Douglas, J.F. 2005. Dietary Specialization Influences the Efficacy of Larval Tortoise Beetle Shield Defenses. Oecologia.

Withers, T. 2014. Eucalyptus Tortoise Beetle Biocontrol. (Online). www.scionresearch.com/service s. Diakses pada 11 November 2018. 